\title{
AC 2008-2907: INCORPORATING DIVERSITY AND INTERNATIONAL AWARENESS INTO AN INTRODUCTION TO ENGINEERING TECHNOLOGY SEMINAR COURSE
}

\section{Andrew Rose, University of Pittsburgh -Johnstown}

Andrew T. Rose is an Associate Professor of Civil Engineering Technology at the University of Pittsburgh at Johnstown (UPJ). Before joining the faculty at UPJ, he was a Staff Engineer with GAI Consultants in Pittsburgh. His teaching interests include soil mechanics, foundation design, structural steel design, structural analysis, and incorporating practical design experience and professional practice issues into the undergraduate civil engineering technology curriculum. Dr. Rose received B.S. and M.S. degrees in Civil Engineering from the University of Connecticut in 1985 and 1986 and a Ph.D. from Virginia Polytechnic Institute and State University in 1995.

\section{Katherine Stahl Kinsinger, University of Pittsburgh -Johnstown}

Kate Stahl-Kinsinger, MA, is the academic support and first-year seminar coordinator at the University of Pittsburgh at Johnstown. Earning her master's in student affairs in higher education, Stahl-Kinsinger has worked in higher education for fourteen years and has a particular interest in helping resistant students become academically successful. 


\title{
Incorporating Diversity and International Awareness into an Introduction to Engineering Technology Seminar Course
}

\begin{abstract}
At the University of

, all freshmen must complete a "University Scholarship" course during their first term to help them transition from high school to college. The course discusses time management, learning styles, study skills, information literacy and library research skills, diversity, and critical thinking. This one-credit course was implemented in the Engineering Technology division by modifying the existing freshmen seminar course to include these topics along with an introduction to engineering careers, engineering technology student organizations, student advising, and balancing school and personal life.

This year, a summer reading assignment was included in the University Scholarship course for all freshmen. Students read Tracy Kidder's book "Mountains Beyond Mountains: The Quest of Dr. Paul Farmer, A Man Who Would Cure the World." The book chronicles the work of Dr. Paul Farmer and his Partners in Health organization to address disease, living and economic conditions, and healthcare in countries such as Haiti, Peru, and Russia. This was coordinated with a University sponsored extracurricular program which included speakers, documentary films, a service learning activity, and a health and wellness fair. Students were required to attend and write about one of the extracurricular activities for the University Scholarship course. For the engineering technology students, a more direct connection between the engineering profession and issues of importance in the global community was desired. To accomplish this, a critical thinking assignment and guest speaker were used. For the critical thinking assignment, students had to research and write about an engineering project that improves the quality of life for a given population. These were chosen from a series of web site articles highlighting humanitarian engineering projects, development initiatives, and sustainability projects in third world countries. To provide a more personal and interactive aspect, guest speakers from a nearby university gave a presentation on their Engineers Without Boarders (EWB) student chapter and their experiences working on EWB projects. The objective was to help freshmen better appreciate diversity and see a global connection between themselves, their engineering technology education and the needs of others throughout the world. Students were surveyed and asked to comment on their view of and appreciation for the benefits involvement in organizations such as EWB and how they might be motivated to become involved in or support such activities in the future.
\end{abstract}

